\title{
STATUS OF AVIFAUNA IN CURZON HALL PREMISES UNIVERSITY OF DHAKA, BANGLADESH
}

\author{
Muntasir Akash, Md. Anwar Hossain, Gawsia Wahidunnessa Chowdhury, \\ Humayra Mahmud and Md. Anwarul Islam \\ Department of Zoology, University of Dhaka, Dhaka 1000, Bangladesh \\ Email: akashmuntasir10@gmail.com, anwar79du@gmail.com,gawsia@gmail.com, \\ humayramahmud@gmail.com, anwar1955@gmail.com
}

\begin{abstract}
In order to estimate the diversity and status of avian species of Curzon Hall premises, University of Dhaka, Bangladesh, a study was conducted from January 2012 to January 2014. A total of 50 species of birds belonging to 30 families under 12 orders were recorded of which, regarding the relative abundance, 29 were common and 21 were uncommon. Twenty five species, in total, were identified as breeding residents, 13 as non-breeding residents and 12 as migrants. Of all the species identified from the study site, one was Critically Endangered (Alexandrine Parakeet Psittacula eupatria) and six were new for the campus (Taiga Flycatcher Ficedula albicilla, Indian Silverbill Lonchura malabarica, Ashy Drongo Dicrurus leucophaeus, Eurasian Wryneck Jynx torquilla, Pied Cuckoo Clamator jacobinus, Lesser Whistling Duck Dendrocygna javanica). Passerines were the dominating group as represented by 27 species from 16 different families. Species richness was in the highest peak in the late winter and early spring and comparatively less in other seasons.
\end{abstract}

Key words: Birds, Dhaka, Bangladesh.

\section{INTRODUCTION}

Avifaunal diversity is one of the most significant indicators in term of ecology to figure out the quality and condition of environment (Bilgrami 1995). At present, avian diversity has been declining due to destruction of natural habitats and human disturbances. As responses to expanding civilization and unplanned urbanization, indiscriminate cutting down of trees for commercial purposes are the main factors responsible for narrowing down the foraging and nesting sites of birds. Thus, many species of birds are forced to inhabit in the urban areas and have evolved new strategies of survival. Therefore, elaborate study on urban avifauna and their ecology is essential to protect them.

Holding a history of exuberant past of about 400 years, the city of Dhaka stands still with pride. The then-urban area was a tapestry more of wetlands, forests, scrub-jungles and grasslands and bound by mighty rivers, crisscrossed by their tributaries and dotted with lakes and ponds. The number and diversity of avian species along with other wild fauna were naturally very much more than it can be summarized today. Regarding the birds, it was more a home for waterfowls, pheasants, partridges, bustards, cranes, storks, eagles, hawks, falcons, owls, herons, egrets, etc 
(Tytler 1854, Simpson 1882) other than present city-birds. Although many birds from Dhaka are now considered to be extirpated, the list of birds of two hundred species seen in Dhaka today (Islam et al. 2010), which is a bit beyond belief considering the land of this mega-city now nearly covered in concrete and all the waters are being drained or poisoned.

At present, despite being an over-populated city (an estimated 12.8 million as of 2008), Dhaka, the capital of Bangladesh, having an area of 360 square kilometers and with a very limited range of habitats for wildlife and yet being damaged at present time, still provides few green spaces served as key areas for birds. And at the city centre, the Curzon Hall compound along with the Dhaka University Campus is considered as a perfect "oasis".

As a part of School of Science Division of University of Dhaka, the Curzon Hall premises $\left(23^{\circ} 43^{\prime} 33.99^{\prime \prime} \mathrm{N} 90^{\circ} 24^{\prime} 9.43^{\prime \prime} \mathrm{E}\right)$ is located in the midst of Dhaka Metropolis. Including the historically and archeologically significant Curzon Hall, within an area of about 9 acres, the premises hold ten other major structures being used for study purposes. The premise is defined by its location in between the city buzz on its north and east, and on its west by the remaining part of the university and peripheral region of a park named Suhrawardy Uddyan. And on its south, along with having a large pond, the area is confluent with boundaries of two dormitories of University of Dhaka.

Though incorporating several bricked structures, the campus has been blueprinted well in terms of plantation consisting of herbs, shrubs, trees, creepers and climbers. In the campus, Ayahuma (Couroupita guianensis), Mahua (Madhuca longifolia), Ficus sp., Gustava sp., Flamboyant (Delonix regia), Parrot tree (Butea monosperma), Mahogani (Swietenia mahagoni), Frywood (Albizia lebbeck and Albizia saman), Cape Lilac (Melia azedarach), Himalayan Cedar (Cedrus deodara), Golden Shower (Cassia fistula),
Pigeonwood (Plumeria sp.), Kadam tree (Neolamarckia cadamba), Ashoka (Saraca asoca), Powderpuff (Calliandra emarginata), Traveler's Palm (Ravenala madagascariensis), Crepe Myrtle (Lagerstroemia sp.), Almond tree (Prunus dulcis) and weed (Lantana sp.), are considered as favourite foraging and nesting sites by the birds.

In the compound, many aquatic reservoirs are implanted with several submerged and floating aquatic plants like Hydrilla sp., Marsilea sp., Nymphaea sp., Nelumbo sp., Echinodorus sp. etc. It is also noteworthy that two gardens under the authority of the Department of Botany, one located at the north-easternmost side of the premises and the other on the southern corner of the compound, are rich in exotic and indigenous plants (from creepers to trees). The garden cited latter named as Centre for Conservation of Medicinal Plants harbors about 100 medicinal plants which in return give the garden a bushy appearance and attracts many garden species of the campus, specially the insectivorous ones. Both gardens serve best for the birds residing in the premises seasonally and permanently.

Despite the fact that Curzon Hall campus is one of the critical areas for birds in Dhaka city, scientific studies on the status of birds are still limited and last one was dated back to about 19 years. (Das 1975, Banerjee 1976 and Sultana 1994). This study was conducted to provide updated information and compilation of information on the status and seasonal occurrence of the avian species recorded in the campus.

\section{MATERIALS AND METHODS}

Field observations were made and birds were identified with the help of two pairs of Super Zenith $20 \times 50$ and Bushnell Powerview $8 \times 42$ binoculars and by hearing distinctive calls (for some species only) and in many cases, for further identification, observed birds were photographed using a Canon 600 D camera with Canon EF-S 55$250 \mathrm{~mm}$ f/4.0-5.6 IS II telephoto zoom lens. 
To locate a bird, emphasis was given on observing the trees located in between the buildings and surveying the garden (stated above)(Fig. 1). Observations were made at a certain distance from the focal animal to minimize interference on its behaviour.

Ali (2002) and Grimmett et al. (1998) were consulted for the identification of birds. The global threat status follows IUCN (2000) and the national threat status as well as the taxonomy and nomenclature follow Siddiqui et al. (2008).

Data were collected by direct observations in the field, during a period of 24 months (January 2012 to January 2014), mainly in the mornings and afternoons, the most active periods for avian species. At least 15 days were spent in every month for the field observations. Only the species with confirmed identification were enlisted. The relative abundance of the birds was assessed as: "Common" (seen in almost each visit) and "Uncommon" (seen only in one or two visits). For winter and summer migrants, the abundance was assessed only during the months when they were present in the Campus.

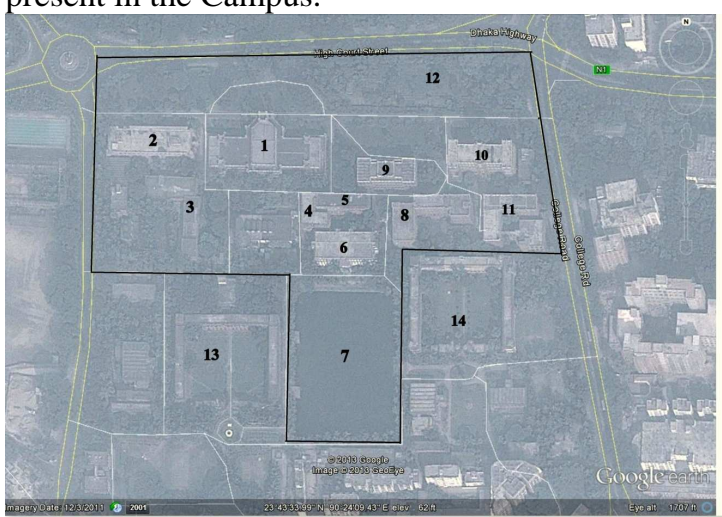

Fig. 1. Map (taken from Google Earth) of Curzon Hall premises, numbers showing the major structures of the area, black line depicting the boundary of the study area

1. Curzon Hall, 2. Department of Applied Physics,

3. Department of Geology, 4. Department of Fisheries,

5. Department of Applied Chemistry, 6. Department of Zoology, 7. Pond, 8. Department of Botany and Centre for Conservation of Medicinal Plants, 9. Department of Chemistry, 10. Department Biochemistry and Molecular Biology, 11. Department of Soil, Water and Environment, 12. Botanical Garden, 13 and 14. Dormitories of University of Dhaka.

\section{RESULTS AND DISCUSSION}

From the premises that had remained unexplored ornithologically in recent time, a total of 50 avian species belonging to 30 families under 12 orders were confirmed and from a viewpoint of relative abundance, $29(58 \%)$ species were Common/Resident, 21 (42\%) Uncommon and 12 (24\%) were migrants (Table 1). Of the 50 species, $27(54 \%)$ were passerine and $23(46 \%)$ were nonpasserine. Vagrant/Occasional birds were observed moving or migrating locally (from the Campus to outside and vice versa) in different seasons.

Among the recorded birds, House Sparrow Passer domesticus, Black Drongo Dicrurus macrocercus, House Crow Corvus splendens, Indian Jungle Crow Corvus macrorhynchos, Redvented Bulbul Pycnonotus cafer, Pied Starling Sturnus contra, Common Myna Acridotheres tristis, Common Tailor-bird Orthotomus sutorius, House Swift Apus affinis, Coppersmith Barbet Megalaima haemacephala, Black-rumped Flameback Dinopium benghalense, Fulvousbreasted Woodpecker Dendrocopos macei, Rufous Woodpecker Micropternus brachyurus, Spotted Dove Spilopelia chinensis, Rock Pigeon Columba livia, Common Kingfisher Alcedo atthis, Black Kite Milvus migrans, Indian Ring-necked Parakeet Psittacula krameri were the species sighted in each visit. Taiga Flycatcher Ficedula albicilla, Ashy Drongo Dicrurus leucophaeus, Clamorous Reed Warbler Acrocephalus stentoreus, Eurasian Wryneck Jynx torquilla, Long-tailed Shrike Lanius schach, Brown Shrike Lanius cristatus, Graybacked Shrike Lanius tephronotus, White Wagtail Motacilla alba leucopsis and Paddyfield Pipit Anthus rufulus were among the winter migrants. Pied Cuckoo Clamator jacobinus was the only summer migrant of the campus. Little Cormorant Microcarbo niger and Lesser Whistling Duck Dendrocygna javanica were recorded as moving locally.

House Sparrow Passer domesticus was a common species for the area, always seen in small flocks foraging on ground or perching in branches. 
A pair of Great Tit Parus major was observed in March 2012 perching on shrubs near the Dept. of Soil, Water and Environment. A pair of Indian Silverbill Lonchura malabarica was also recorded for a day long on April 3, 2013 foraging and perching on the bushes at campus-adjacent bank of dormitory's pond.

Table 1. Birds in Curzon Hall campus with population status, migration status, and seasonal occurrence. (Population status code: C - Common, and UC - Uncommon; CR - Critically Endangered, and LC - Least Concerned. Breeding and migration status code: $\mathrm{Br}$ - Breeding Resident, $\mathrm{NBr}-\mathrm{Non}-$ breeding Resident, $\mathrm{M}_{\mathrm{w}}$ - Wintering Migrant, $\mathrm{M}_{\mathrm{l}}$ - Local Migrant. Seasonal occurrence code: $\mathrm{YR}$ - Yearround)

\begin{tabular}{|c|c|c|c|c|}
\hline $\mathbf{S N}$ & $\begin{array}{c}\text { Species (Scientific and English } \\
\text { name) }\end{array}$ & $\begin{array}{c}\text { Population status- } \\
\text { global, national, local }\end{array}$ & $\begin{array}{l}\text { Breeding and migration } \\
\text { status (breeding season) }\end{array}$ & $\begin{array}{c}\text { Seasonal } \\
\text { occurrence }\end{array}$ \\
\hline 1 & $\begin{array}{l}\text { Passer domesticus House } \\
\text { Sparrow }\end{array}$ & $--, \mathrm{C}, \mathrm{C}$ & $\mathrm{Br}$ (all months) & YR \\
\hline 2 & Parus major Great Tit & $--, \mathrm{C}, \mathrm{UC}$ & $\mathrm{NBr}$ & Mar 2012 \\
\hline 3 & $\begin{array}{l}\text { Lonchura malabarica Indian } \\
\text { Silverbill }\end{array}$ & $\mathrm{LC}, \mathrm{UC}, \mathrm{UC}$ & $\mathrm{NBr}$ & Apr 2013 \\
\hline 4 & $\begin{array}{l}\text { Dicrurus macrocercus Black } \\
\text { Drongo }\end{array}$ & $\mathrm{LC}, \mathrm{C}, \mathrm{C}$ & Br (Mar-Aug) & YR \\
\hline 5 & $\begin{array}{l}\text { Dicrurus leucophaeus Ashy } \\
\text { Drongo }\end{array}$ & $\mathrm{LC}, \mathrm{UC}, \mathrm{UC}$ & $\mathrm{M}_{\mathrm{w}}$ & Dec-Jan \\
\hline 6 & Corvus splendens House Crow & LC, C, C & $\mathrm{Br}$ (Feb-Jun) & YR \\
\hline 7 & $\begin{array}{l}\text { Corvus macrorhynchos Indian } \\
\text { Jungle Crow }\end{array}$ & $\mathrm{LC}, \mathrm{C}, \mathrm{C}$ & Br (Nov-Apr) & YR \\
\hline 8 & $\begin{array}{l}\text { Dendrocitta vagabunda Rufous } \\
\text { Treepie }\end{array}$ & $\mathrm{LC}, \mathrm{C}, \mathrm{C}$ & $\mathrm{NBr}$ & YR \\
\hline 9 & $\begin{array}{l}\text { Pycnonotus cafer Red-vented } \\
\text { Bulbul }\end{array}$ & $\mathrm{LC}, \mathrm{C}, \mathrm{C}$ & $\mathrm{Br}$ (Apr-Sep) & YR \\
\hline 10 & $\begin{array}{l}\text { Pycnonotus jocosus Red- } \\
\text { whiskered Bulbul }\end{array}$ & $\mathrm{LC}, \mathrm{C}, \mathrm{UC}$ & $\mathrm{NBr}$ & Mar 2012 \\
\hline 11 & $\begin{array}{l}\text { Lanius schach Long-tailed } \\
\text { Shrike }\end{array}$ & $\mathrm{LC}, \mathrm{C}, \mathrm{UC}$ & $\mathrm{M}_{\mathrm{w}}$ & Feb 2012 \\
\hline 12 & Lanius cristatus Brown Shrike & $\mathrm{LC}, \mathrm{C}, \mathrm{C}$ & $\mathrm{M}_{\mathrm{w}}$ & Nov-Apr \\
\hline 13 & $\begin{array}{l}\text { Lanius tephronotus Gray- } \\
\text { backed Shrike }\end{array}$ & $\mathrm{LC}, \mathrm{UC}, \mathrm{UC}$ & $\mathrm{M}_{\mathrm{w}}$ & Nov-Jan \\
\hline 14 & $\begin{array}{l}\text { Acrocephalus stentoreus } \\
\text { Clamorous Reed Warbler }\end{array}$ & $\mathrm{LC}, \mathrm{C}, \mathrm{UC}$ & $\mathrm{M}_{\mathrm{w}}$ & Jan 2012 \\
\hline 15 & $\begin{array}{l}\text { Nectarinia asiatica } \text { Purple } \\
\text { Sunbird }\end{array}$ & $--, C, C$ & Br (Mar-Aug) & YR \\
\hline 16 & $\begin{array}{l}\text { Ficedula albicilla Taiga } \\
\text { Flycatcher }\end{array}$ & $\mathrm{LC}, \mathrm{C}, \mathrm{UC}$ & $\mathrm{M}_{\mathrm{w}}$ & Nov-Feb \\
\hline 17 & $\begin{array}{l}\text { Copsychus saularis Oriental } \\
\text { Magpie Robin }\end{array}$ & $\mathrm{LC}, \mathrm{C}, \mathrm{C}$ & Br (Mar-July) & YR \\
\hline 18 & $\begin{array}{l}\text { Acridotheres fuscus Jungle } \\
\text { Myna }\end{array}$ & LC, C, C & Br (Feb-July) & YR \\
\hline 19 & $\begin{array}{l}\text { Acridotheres tristis Common } \\
\text { Myna }\end{array}$ & $\mathrm{LC}, \mathrm{C}, \mathrm{C}$ & Br (Mar-Aug) & YR \\
\hline 20 & $\begin{array}{l}\text { Sturnia malabarica } \text { Chestnut- } \\
\text { tailed Starling }\end{array}$ & LC, C, C & Br (Apr-July) & YR \\
\hline
\end{tabular}




\begin{tabular}{|c|c|c|c|c|}
\hline 21 & Sturnus contra Pied Starling & LC, C, C & $\mathrm{Br}$ (Mar-Sep) & YR \\
\hline 22 & Aegithina tiphia Common Iora & $\mathrm{LC}, \mathrm{C}, \mathrm{UC}$ & $\mathrm{NBr}$ & Jan 2014 \\
\hline 23 & $\begin{array}{l}\text { Dicaeum erythrorhynchos Pale- } \\
\text { billed Flowerpecker }\end{array}$ & $\mathrm{LC}, \mathrm{C}, \mathrm{UC}$ & $\mathrm{NBr}$ & Jan 2014 \\
\hline 24 & $\begin{array}{l}\text { Orthotomus sutorius Common } \\
\text { Tailor-bird }\end{array}$ & $\mathrm{LC}, \mathrm{C}, \mathrm{C}$ & Br (Apr-July) & YR \\
\hline 25 & $\begin{array}{l}\text { Oriolus xanthornus Black- } \\
\text { hooded Oriole }\end{array}$ & $\mathrm{LC}, \mathrm{C}, \mathrm{C}$ & Br (Mar-Sep) & YR \\
\hline 26 & $\begin{array}{l}\text { Motacilla alba leucopsis White } \\
\text { Wagtail }\end{array}$ & $\mathrm{LC}, \mathrm{C}, \mathrm{UC}$ & $\mathrm{M}_{\mathrm{w}}$ & Dec-Mar \\
\hline 27 & Anthus rufulus Paddyfield Pipit & $\mathrm{LC}, \mathrm{C}, \mathrm{UC}$ & $\mathrm{M}_{\mathrm{w}}$ & Feb 2012 \\
\hline 28 & Apus affinis House Swift & $\mathrm{LC}, \mathrm{C}, \mathrm{C}$ & Br (Apr-July) & YR \\
\hline 29 & $\begin{array}{l}\text { Cypsiurus balasiensis Palm } \\
\text { Swift }\end{array}$ & $\mathrm{LC}, \mathrm{C}, \mathrm{C}$ & $\mathrm{Br}(\mathrm{YR})$ & YR \\
\hline 30 & $\begin{array}{l}\text { Eudynamys scolopacea Asian } \\
\text { Koel }\end{array}$ & $\mathrm{LC}, \mathrm{C}, \mathrm{C}$ & Br (Mar-July) & YR \\
\hline 31 & $\begin{array}{l}\text { Clamator jacobinus Pied } \\
\text { Cuckoo }\end{array}$ & $\mathrm{LC}, \mathrm{UC}, \mathrm{UC}$ & $\mathrm{M}_{\mathrm{s}}$ & Sep 2013 \\
\hline 32 & $\begin{array}{l}\text { Cacomantis merulinus } \\
\text { Plaintive Cuckoo }\end{array}$ & $\mathrm{LC}, \mathrm{C}, \mathrm{UC}$ & $\mathrm{NBr}$ & Nov 2013 \\
\hline 33 & $\begin{array}{l}\text { Megalaima haemacephala } \\
\text { Coppersmith Barbet }\end{array}$ & $\mathrm{LC}, \mathrm{UC}, \mathrm{C}$ & Br (Nov-Jun) & YR \\
\hline 34 & $\begin{array}{l}\text { Dendrocopos macei Fulvous - } \\
\text { breasted Woodpecker }\end{array}$ & $\mathrm{LC}, \mathrm{C}, \mathrm{C}$ & Br (Apr-May) & YR \\
\hline 35 & $\begin{array}{l}\text { Dinopium benghalense Black- } \\
\text { rumped Flameback }\end{array}$ & $\mathrm{LC}, \mathrm{C}, \mathrm{C}$ & $\mathrm{Br}$ (Feb-July) & YR \\
\hline 36 & $\begin{array}{l}\text { Micropternus brachyurus } \\
\text { Rufous Woodpecker }\end{array}$ & $\mathrm{LC}, \mathrm{C}, \mathrm{C}$ & $\mathrm{NBr}$ & YR \\
\hline 37 & $\begin{array}{l}\text { Jynx torquilla Eurasian } \\
\text { Wryneck }\end{array}$ & $\mathrm{LC}, \mathrm{UC}, \mathrm{UC}$ & $\mathrm{M}_{\mathrm{w}}$ & Feb 2013 \\
\hline 38 & $\begin{array}{l}\text { Spilopelia chinensis Spotted } \\
\text { Dove }\end{array}$ & $\mathrm{LC}, \mathrm{C}, \mathrm{C}$ & $\mathrm{Br}(\mathrm{YR})$ & YR \\
\hline 39 & Columba livia Rock Pigeon & LC, C, C & $\mathrm{Br}(\mathrm{YR})$ & YR \\
\hline 40 & $\begin{array}{l}\text { Halcyon smyrnensis } \text { White- } \\
\text { breasted Kingfisher }\end{array}$ & $\mathrm{LC}, \mathrm{C}, \mathrm{UC}$ & $\mathrm{NBr}$ & YR \\
\hline 41 & $\begin{array}{l}\text { Alcedo atthis Common } \\
\text { Kingfisher }\end{array}$ & $\mathrm{LC}, \mathrm{C}, \mathrm{C}$ & Br (Mar-Jun) & YR \\
\hline 42 & $\begin{array}{l}\text { Merops orientalis Green Bee- } \\
\text { eater }\end{array}$ & $\mathrm{LC}, \mathrm{C}, \mathrm{UC}$ & $\mathrm{NBr}$ & YR \\
\hline 43 & $\begin{array}{l}\text { Psittacula krameri Indian Ring- } \\
\text { necked Parakeet }\end{array}$ & $\mathrm{LC}, \mathrm{C}, \mathrm{C}$ & Br (Jan-July) & YR \\
\hline 44 & $\begin{array}{l}\text { Psittacula eupatria Alexandrine } \\
\text { Parakeet }\end{array}$ & $\mathrm{CR}, \mathrm{CR}, \mathrm{UC}$ & $\mathrm{NBr}$ & $\begin{array}{c}\text { Mar 2012, } \\
\text { Feb 2013 }\end{array}$ \\
\hline 45 & Milvus migrans Black Kite & $\mathrm{LC}, \mathrm{C}, \mathrm{C}$ & Br (Dec-May) & YR \\
\hline 46 & Haliastur indus Brahminy Kite & LC, C, C & $\mathrm{NBr}$ & YR \\
\hline 47 & Athene brama Spotted Owlet & $\mathrm{LC}, \mathrm{C}, \mathrm{C}$ & $\mathrm{Br}$ (Nov-Apr) & YR \\
\hline 48 & Ardeola grayii Pond Heron & LC, C, UC & $\mathrm{NBr}$ & Jan 2013 \\
\hline 49 & $\begin{array}{l}\text { Microcarbo niger Little } \\
\text { Cormorant }\end{array}$ & $\mathrm{LC}, \mathrm{C}, \mathrm{UC}$ & $\mathrm{M}_{1}$ & Nov 2012 \\
\hline 50 & $\begin{array}{l}\text { Dendrocygna javanica Lesser } \\
\text { Whistling Duck }\end{array}$ & LC, C, UC & $\mathrm{M}_{1}$ & Jan 2014 \\
\hline
\end{tabular}


Black Drongo Dicrurus macrocercus, House Crow Corvus splendens, Indian Jungle Crow Corvus macrorhynchos were common throughout the campus. Black Drongo was recorded mostly from the Botanical Garden. Crows were found everywhere in the premises. An individual of Ashy Drongo Dicrurus leucophaeus was found wintering from December 2013 to January 2014 at the north-eastern corner of the Botanical Garden. Rufous Treepie Dendrocitta vagabunda was recorded as pair perching mostly from the Ficus sp. in front of the Science Workshop.

Red-vented Bulbul Pycnonotus cafer was reported as a common resident of the campus, always seen in moderately sized flock. Along with about 10 to 15 individuals, a pair of Red-whiskered bulbul Pycnonotus jocosus was recorded in late spring 2012 foraging on flowers of Acacia sp. planted in front of the Department of Botany.

Brown Shrike Lanius cristatus was a common winter visitor. One was recorded from the botanical garden. Long-tailed Shrike Lanius schach was sighted for once from the Botanical Garden in February 2012. Gray-backed Shrike Lanius tephronotus was the third species among the shrikes that had been recorded from the premises. An individual was sighted at the Botanical Garden during the whole winter from November 2013 to January 2014.

Common Myna Acridotheres tristis was seen most of the times on the ground associated with Pied Starling Sturnus contra. Both were common residents of the campus. Jungle Myna Acridotheres fuscus was relatively less in number. However, two pairs built nest in Cape Lilac tree Melia azedarach beside the Department of Biochemistry and Molecular Biology. In fruiting season, a flock of 20 to 25 Chestnut-tailed Starling Sturnus malabaricus was observed foraging in Ficus sp. located in front of the Science Workshop. The species became most abundant in the area when Parrot Tree Butea monosperma was flowering.
Oriental Magpie Robin Copsychus saularis was found as a common resident of the premises. Five to six males recorded with well established territory. Another muscicapid was observed from the site was Taiga flycatcher Ficedula albicilla, a common winter visitor and a new record for the campus. One individual was observed for two consecutive winters, establishing territory in the Botanical Garden. Common Tailor Bird Orthotomus sutorius and Purple Sunbird Nectarinia asiatica were the species found commonly in the year-round study.

In mid-winter 2012, one individual of Clamorous Reed Warbler Acrocephalus stentoreus was recorded foraging and perching in the bushes in front of the Department of Zoology.

Common Iora Aegithina tiphia and Pale-billed Flowerpecker Dicaeum erythrorhynchos were sighted from the campus in January 2014. Single individual from each species was seen foraging in the trees behind the Department of Botany.

Throughout the study, a Critically Endangered species was recorded and it was Alexandrine Parakeet Psittacula eupatria. In late spring 2012 two individuals were seen flying around Eucalyptus sp. and Almond tree Prunus dulcis in front of the Department of Biochemistry and Molecular Biology and probably were cageescapees. Necessary photographs were taken. Large size and bold maroon patch on the wing were unmistakably conspicuous.

Among wagtails and pipits, White Wagtail Motacilla alba leucopsis and Paddyfield Pipit Anthus rufulus were winter migrants. One individual of the latter species was observed in a mid-winter morning in February 2012 from the Botanical Garden.

In March 2012, for the first time, a pair of Coppersmith Barbet Megalaima haemacephala was recorded residing in Cape Lilac situated on the east side of the Department of Chemistry. The tree had been used as a regular nesting site for the tree. 
Indian Pond Heron Ardeola grayii, Little Cormorant Microcarbo niger and Lesser Whistling Duck Dendrocygna javanica were uncommon species of the campus. Among these, of the first one, in Jaunary 10, 2013, an individual was seen flying in the plantation located on the dorm-side bank of the pond in the campus. The last two species were possibly passage migrants and moving locally. A pair of each species had been observed swimming in the dormitory's pond for a day long on November 14, 2012 and January 29, 2014, respectively.

The campus area was found to be used as foraging and nesting site of two species of swifts. The largest colony of House Swift Apus affinis resides in the Curzon Hall building and is used to fly in scattered flock during early morning and late afternoon. Palm Swift Cypsiurus balasiensis was mostly seen flying around exotic Palm trees planted as avenue trees in the area.

Black-hooded Oriole Oriolus xanthornus was sighted abundantly during spring and identified mostly with its distinctive calls. Green Bee-eater Merops orientalis was another species which made its presence in the highest peak during spring and usually seen in small flocks. White-breasted Kingfisher Halcyon smyrnensis was an uncommon species of the study site and mostly a pair was recorded perching on the Frywood tree Albizia lebbeck from the campus side bank of the pond. Spotted Owlet Athene brama was the only species from the order Strigiformes sighted from the premises and mostly identified while making its distinctive calls in the evening. Though recorded as common species, during the study period, Brahminy Kite Haliastur indus was never found roosting or perching on campus trees; records were made after observing soaring individuals.

The study area is found to be a good breeding ground for brood parasitic Asian Koel Eudynamys scolopacea. Three pairs were observed engaged in parasitizing the nests of House Crow during late spring. The campus area had been seen being used as foraging ground by an individual of Pied Cuckoo Clamator jacobinus in September 2013. This species turned out to be the only summer visitor of the study site. It had been sighted for the whole month, especially near Science Workshop and behind the Department of Botany. Plaintive cuckoo Cacomantis merulinus was the third species from Cuculidae that had been observed in the premises. It was enlisted as uncommon resident as sighted once in mid-November 2013.

From woodpeckers' family Picidae, Eurasian Wryneck Jynx torquilla was the only migratory species of Curzon Hall. It was sighted once in February 11, 2013 from south-eastern side (campus-adjacent) of dormitory's pond foraging on a large Frywood tree.

The presence of 50 avian species indicates the richness of the biodiversity of Curzon Hall area. Total avian diversity of the campus is dominated by passerines, as 27 different species from 16 different families represent the order. Along with this observation, 11 different non-passerine orders represented by 14 different families were also recorded.

Although enlisted by Banerjee (1976), Indian Roller Coracias benghalensis, Scaly-breasted Munia Lonchura punctulata, Jungle Babbler Turdoides striatus, Common Woodshrike Tephrodornis pondicerianus were not sighted during the study period. This might be due to loss of habitats and plantation of exotics.

In Curzon Hall compound, winter migrants reached its peak abundance in January and other species, mostly residents, became most abundant in spring (late February and March) in a response to the blooming and fruiting of the campus trees and to consequently higher food availability. Birds like Common Kingfisher Alcedo atthis, White-breasted Kingfisher Halcyon smyrnensis, House Swift Apus affinis, and Green Bee-eater Merops orientalis seemed to remain concentrated on the vicinity of the large perennial waterbody of the premises. 
As a rule, the urban ecosystem follows the same principles as other ecosystems. The difference, though, is that here the changes are drastic and rapid so pose a severe challenge to biodiversity and its environs. However, an advantage is that cities and towns are on average five degrees warmer than the countryside. This gives the urban regions a longer growing season and offers advantages to many life forms (necessarily including avian species, which have a relatively higher rate of metabolism). Though there is a tendency to disregard the urban environment because of its apparently minimal ecological value, the green spaces and the wisely designed public parks of a mega-city could serve as good refuge for many threatened flora and fauna. Situating just right at the city centre, the Curzon Hall compound was and still is doing a significant job in this regard. Since remote past, greenery in its compound successfully serves as an attraction piece to several species of birds as well as other wildlife still thriving in the city buzz.

Though located in the midst of city, the Curzon Hall premises seemed relatively free of anthropogenic disturbances. As canopy birds and open-country species are observed here, it is suggested that concentration on incorporating native trees, shrubs, and vines should be grown on this campus, as native plants are likely to provide the right mix, size, and nutritional values that birds require.

\section{ACKNOWLEDGEMENTS}

Thanks are due to Samiul Mohasanin and Sayam U. Chowdhury for confirming the identification of Clamorous Reed Warbler Acrocephalus stentoreus. All relevant taxonomic publications were provided by Noazesh Knowledge Centre of WildTeam.

\section{REFERENCES}

Ali, S. 2002. The Book of Indian Birds (Thirteenth Edition, revised). Oxford University Press, New Delhi.

Banerjee, R.K. 1976. Status and composition of avifauna of the Curzon Hall Campus and Ramna Park. M.Sc. Thesis, Department of Zoology, University of Dhaka, Dhaka.

Bilgrami, K.S. 1995. Concept and Conservation of Biodiversity. CBS Publishers and Distributors, New Delhi.

Das, A.K. 1975. Status and composition of avifauna of the Curzon Hall Campus and Ramna Park. M.Sc. Thesis, Department of Zoology, University of Dhaka, Dhaka.

Grimmett, R., C. Inskipp and T. Inskipp. 1999. Pocket Guide to the Birds of the Indian Subcontinent. Oxford University Press, New Delhi.

Islam, M.A., S.U. Ahmed and A.K.M.G. Rabbani. (eds.). 2010. Environment of Capital Dhaka: Plants Wildlife Gardens Parks Open Spaces Air Water Earthquake. Asiatic Society of Bangladesh, Dhaka.

IUCN Bangladesh. 2000. Red Book of Threatened Birds of Bangladesh. IUCN - The World Conservation Union, Dhaka.

Siddiqui, K.U., M.A. Islam, S.M.H. Kabir, M. Ahmad, A.T.A. Ahmed, A.K.A. Rhaman, E.U. Haque, Z.U. Ahmed, Z.N.T. Begum, M.A. Hassan, M. Khondker and M.M. Rahman. (eds.). 2008. Encyclopedia of Flora and Fauna of Bangladesh. Vol. 26. Birds. Asiatic Society of Bangladesh, Dhaka.

Simpson, F.B. 1882. Notes on birds found near Dacca. Ibis. 4(6):84-95.

Sultana, D. 1994. Bird population of Curzon Hall Campus. M.Sc. Thesis, Department of Zoology, University of Dhaka, Dhaka

Tytler, R.C. 1854. Miscellaneous notes on the fauna of Dacca. The Annals and Magazine of Natural History. 2(14):168-177. 